\title{
Pembuatan Antarmuka Sistem Pemantau Ruangan Berbasis Web
}

\author{
Ruli Handrio*), R. Rizal Isnanto, Eko Didik Widianto \\ Program Studi Sistem Komputer, Fakultas Teknik, Universitas Diponegoro \\ Jl. Prof. Soedarto, SH, Kampus Undip Tembalang, Semarang, Indonesia 50275
}

\begin{abstract}
As the advancement of technology, there are a lot of things that could be efficiently done by technology. technology of surveillance system is necessary and highly demanded by many people at the current momment. The interface of room surveillance system using PHP programming language and MySQL as a database management system which can generate video and other information as an output in web based browser.The results of this research is an interfaces of surveillance systems that can be used as room monitoring. The result of the Black box testing from this interface of surveillance system indicates that all of the system function has been successfully operated. Hopefully this research can be used to help for further research.
\end{abstract}

Keywords - Interface; PHP; MySQL; Web; Video

Abstrak - Seiring dengan perkembangan teknologi, banyak hal yang dapat diselesaikan secara mudah oleh teknologi tersebut. Teknologi sistem pemantauan juga sangat diperlukan dan diminati oleh banyak orang saat ini. Pembuatan antarmuka sistem pemantau ruang ini menggunakan bahasa pemrograman $P H P$ dan MySQL sebagai manajemen basisdata yang dapat menghasilkan video dan juga informasi sebagai keluaranya melalui web browser. Hasil dari pengujian Black box dari antarmuka sistem pemantau ruang ini menunjukan bahwa semua fungsi dari sistem sudah berhasil berjalan. Diharapkan penelitian ini dapat digunakan untuk membantu penelitian - penelitian kedepanya.

Kata Kunci - antarmuka; PHP; MySQL; Web; Video

\section{PENDAHULUAN}

Seiring dengan perkembangan zaman, banyak hal yang dapat diselesaikan dengan teknologi. Dalam perkembangannya, teknologi sistem pemantau ruangan juga sangat dibutuhkan dan diminati oleh banyak orang. Kebutuhan akan kenyamanan dan keamanan mendorong banyak orang mengembangkan teknologi untuk pemantauan, tidak terlepas dari keadaaan sosial di lingkungan kita yang berpengaruh pada tingkat kriminalitas di lingkungan tersebut ${ }^{[5]}$.

Sistem pemantau ruang sendiri sudah banyak dikembangkan salah satunya dengan menggunakan motion. Motion sendiri adalah aplikasi untuk mengoperasikan kamera pengintai pada linux. Motion hanya bekerja pada linux yang mendukung video kamera termasuk semua webcam seperti ip kamera, axis kamera dan lainnya.

Dalam melakukan penelitian mengenai pembuatan antarmuka sistem pemantau ruang berbasis web mengambil beberapa referensi dari artikel terkait sistem aplikasi dan fitur-fiturnya, beberapa poin yang dapat disimpulkan diantaranya Pada artikel "Perancangan Prototype Web-Based Online Smart Home Controlled By Smartphone”, aplikasi sudah dapat dijalankan dengan menggunakan perangkat berbasis dekstop dan juga mobile, akan tetapi aplikasi belum mempunyai fitur keamanan pengguna seperti jika pengguna lupa kata sandi dan juga fitur laporan perekaman ${ }^{[1]}$, kemudian Pada artikel "Aplikasi Webcam Untuk Mendeteksi Gerakan Suatu Objek”, aplikasi ini dibangun dengan menggunakan bahasa pemrograman $\mathrm{C \#}$ dan lebih membahas tentang sistem pendeteksi ${ }^{[2]}$. Pada artikel "Perancangan Kamera Pemantau Nirkabel Menggunakan Raspberry Pi Model B”, aplikasi ini sudah dapat menampilkan live stream melalui browser akan tetapi belum ada antarmuka responsif yang dikembangkan untuk memfasilitasi sistem ini ${ }^{[3]}$.

Dari referensi penelitian sebelumnya dan melalui penilitian ini akan dibangun sebuah antarmuka sistem pemantau ruangan berbasis web yang dapat melakukan proses live stream, melihat laporan hasil perekaman yang berupa diagram, dan dapat mengakses video yang terekam baik melalui proses memutar video secara langsung dan juga mengunduh video yang dapat diakses melalui dekstop browser maupun mobile browser, serta menambahkan fitur keamanan aplikasi dengan proses login dan juga perancangan antarmuka yang responsif yang bertujuan untuk mempermudah pengguna untuk melakukan proses pemantauan ruangan berbasis web. Pada aplikasi ini juga terdapat keluaran yaitu rekaman video pergerakan yang di didapat dari perekaman video secara langsung dan juga diagram sebagai laporanya.

\section{METODE PENELITIAN}

Tahapan yang digunakan untuk merancang aplikasi ini adalah analisis kebutuhan, perancangan, dan implementasi.

Aplikasi ini dirancang dengan berbasis web, dimana jenis aplikasi berbasis web ini menggunakan browser untuk menjalankan aplikasi dan diakses melalui jaringan komputer ${ }^{[7]}$. Aplikasi berbasis web juga akan memudahkan pengguna yang ingin menggunakan aplikasi dimanapun dan kapanpun.

*) Penulis Korespondensi (Ruli Handrio)

Email: rulihandrio@gmail.com 
Aplikasi ini dapat diakses melalui dekstop maupun mobile browser [8-9].

Pada tahap perancangan sistem dan perangkat lunak dimulailah perancangan aplikasi yang disesuaikan dengan konsep yang telah dibuat sebelumnya. Pada tahap perancangan sistem ini akan digambarkan secara umum sistem yang akan dibuat dengan menggunakan beberapa diagram UML yang memiliki fungsi-fungsi yang berbeda dalam menggambarkan suatu sistem. Dalam menggambarkan kebutuhan sistem digunakan Use Case Diagram, untuk kebutuhan dari aplikasi ini dapat dilihat pada Gambar 1. Gambar 2 dapat dilihat keterkaitan antara pengguna dengan video. Aplikasi ini mempunyai fitur - fitur utama dimana Admin dapat memutar video, mengunduh video, menghapus video, membuat akun baru, menghapus akun, menambahkan kamera, menghapus kamera sedangkan pengguna biasa dapat memutar video, memutar stream, melihat halaman report, mengganti password, serta mengganti email.

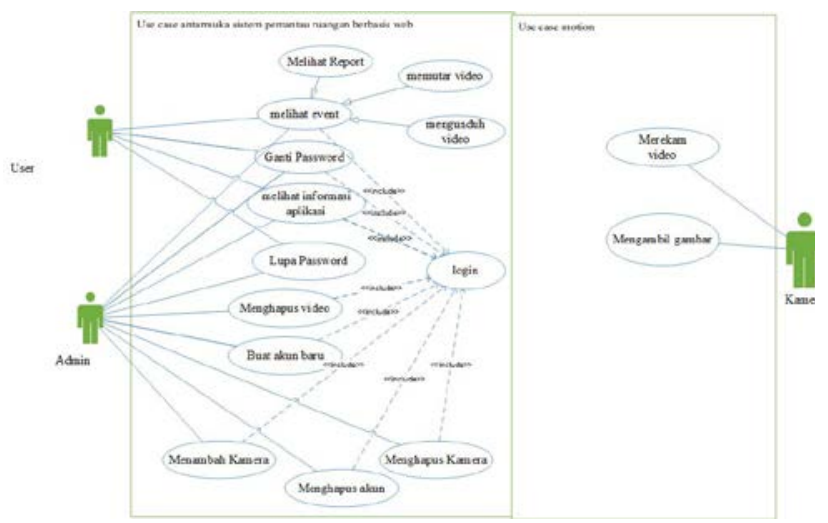

Gambar 1. Use case diagram

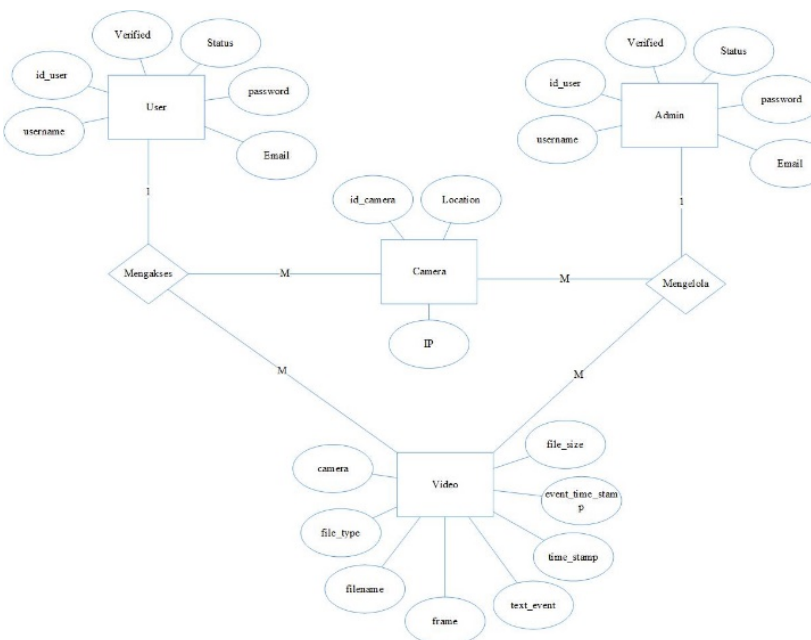

Gambar 2. ERD antarmuka

Setelah melakukan perancangan use case dan juga ERD dibuatlah basisdata untuk aplikasi yang terdapat 4 tabel yaitu tabel camera, security, token, dan user. Gambar 3 menunjukan gambar tabel pada basisdata.

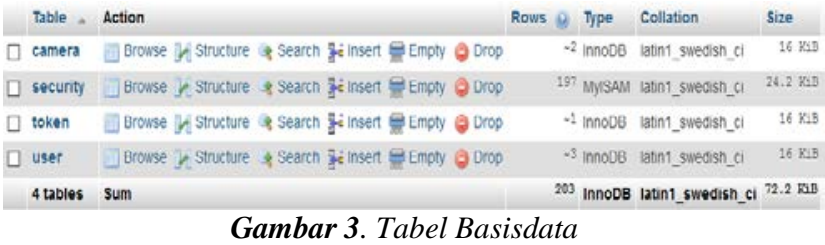

Perancangan layout antarmuka merupakan tahapan yang dilakukan berikutnya yang bertujuan untuk memberikan gambaran secara umum dari aplikasi yang akan dibangun. Gambar 4 menunjukan layout dashboard pada aplikasi yang berguna untuk melakukan live stream dari kamera, Gambar 5 merupakan rancangan layout report yang berguna untuk melihat laporan perekaman, Gambar 6 merupakan rancang layout record untuk melihat hasil video berdasarkan kalender, kemudian Gambar 7 menunjukan rancang layout account setting untuk melakukan pengaturan akun.

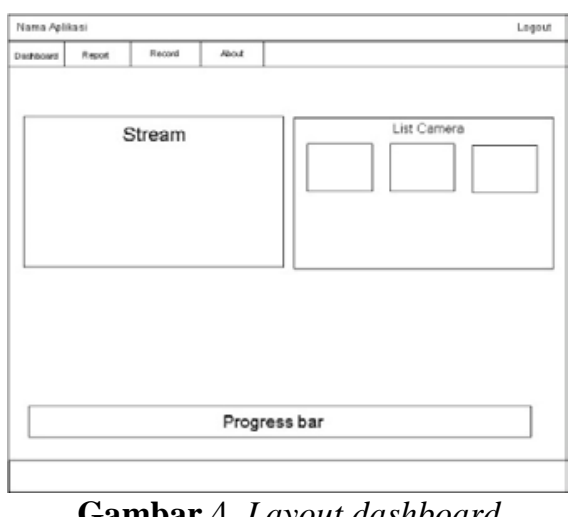

Gambar 4. Layout dashboard

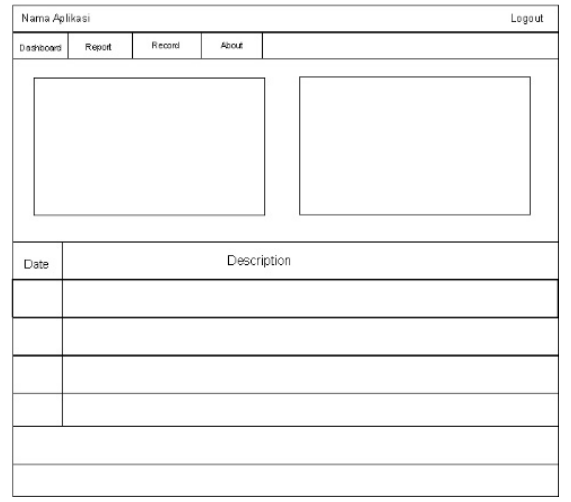

Gambar 5. Layout report

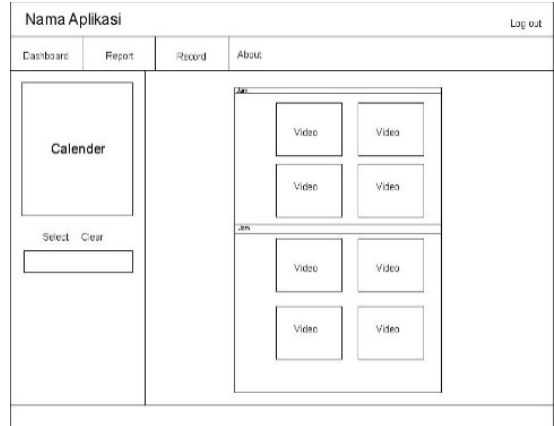

Gambar 6. Layout record 


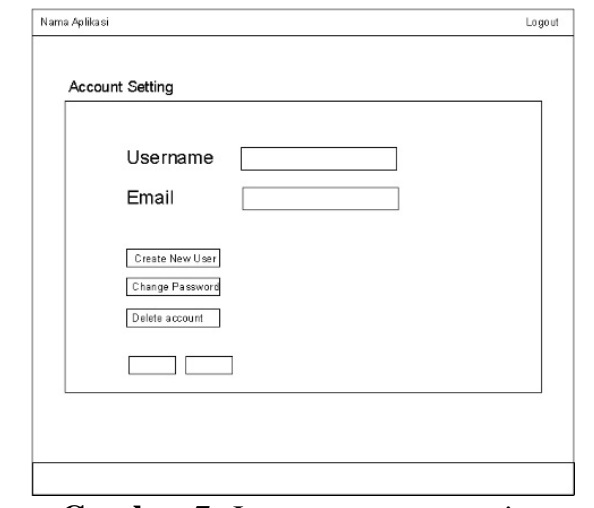

Gambar 7. Layout account setting

\section{HASIL DAN PEMBAHASAN}

Pembuatan antarmuka ini dilakukan secara terurut berdasarkan kebutuhan dari sistem itu sendiri, oleh karena itu pada pembuatan aplikasi ini yang pertama dibuat adalah basisdata dan tahap selanjutnya adalah pembuatan layout aplikasi. Pembuatan aplikasi dilakukan dengan membuat setiap menu. Tabel 1 menunjukkan setiap menu dan fungsi dari menu tersebut. Framework yang digunakan adalah Codeigniter dengan Bootstrap [10-12]

Tabel 1. Daftar menu dan fungsinya

\begin{tabular}{ll}
\hline Menu & Fungsi \\
Login & $\begin{array}{l}\text { Memverifikasi pengguna yang akan } \\
\text { masuk kedalam sistem }\end{array}$ \\
Dashboard & $\begin{array}{l}\text { Menambah / Menghapus kamera dan } \\
\text { melihat stream pada kamera }\end{array}$ \\
Report & $\begin{array}{l}\text { Melihat statistik dari video yang } \\
\text { terekam oleh sistem }\end{array}$ \\
Record & $\begin{array}{l}\text { Melihat video masuk, mengunduh dan } \\
\text { menghapus video }\end{array}$ \\
About & $\begin{array}{l}\text { Melihat profil dari pembuat aplikasi } \\
\text { dan kegunaan sistem }\end{array}$ \\
Account & $\begin{array}{l}\text { Menghapus } \text { user, membuat akun baru, } \\
\text { Setting }\end{array}$ \\
\hline
\end{tabular}

Gambar 8 menunjukkan tampilan menu dashboard dimana fungsi-fungsi pada menu tersebut sudah berjalan dengan baik, Gambar 9 menunjukan tampilan dari menu report yang berisi tentang statistik dari video terekam, menu ini juga sudah berjalan sesuai fungsinya, Gambar 10 menunjukkan menu record dimana fungsi menu untuk melihat video sesuai tanggal dan mengunduh juga sudah berfungsi dengan baik, Gambar 11 menunjukkan tampilan menu account setting dimana menu ini berfungsi untuk membuat akun baru untuk admin dan juga mengganti password, mengganti email untuk pengguna biasa juga sudah berfungsi dengan baik.

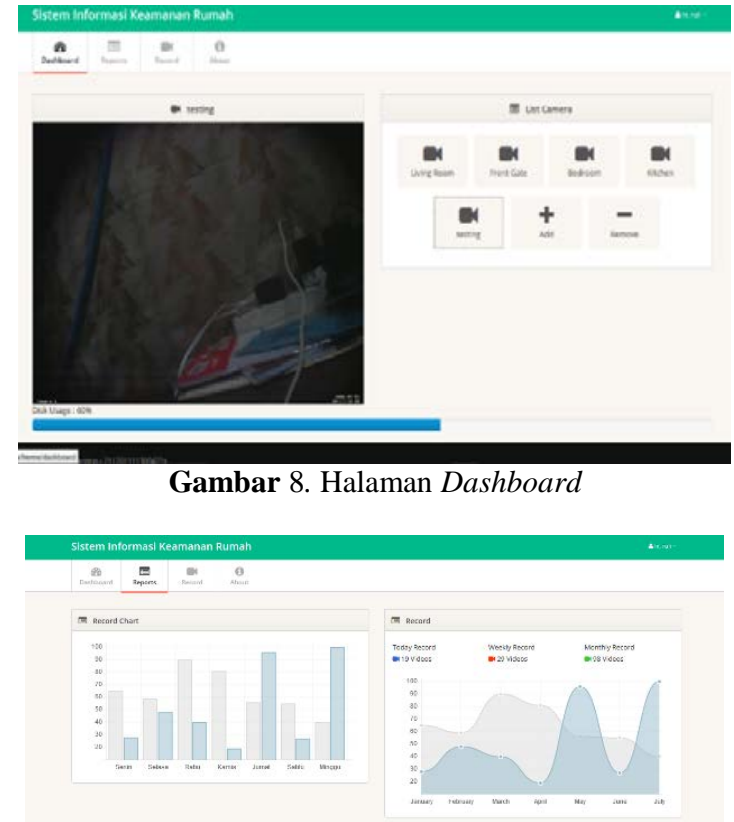

Gambar 9. Halaman Report

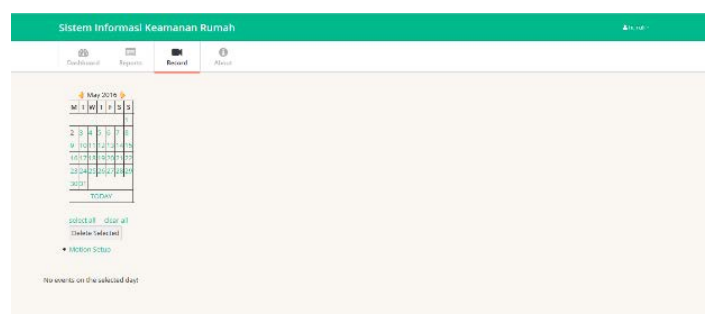

Gambar 10. Halaman Record

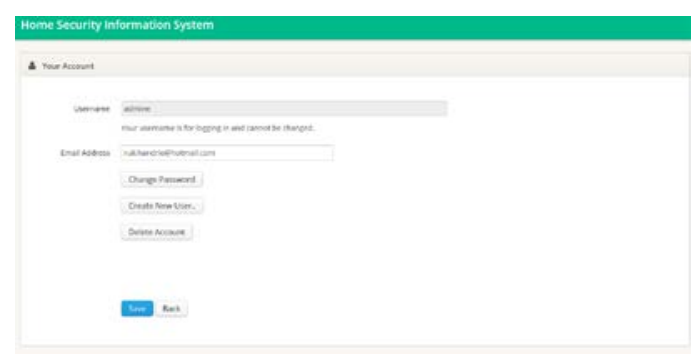

Gambar 11. Halaman Account setting

Semua menu dan fungsi untuk antarmuka sistem pemantau ruangan berbasis web sudah berhasil dibuat dan sesuai dengan kebutuhan dari perancangan tampilan dan juga perancangan terhadap fungsifungsi yang dibutuhkan. Untuk menguji apakah setiap menu dan fungs berjalan dengan baik, dilakukan pengujian lebih lanjut.

Pengujian antarmuka sistem pemantau ruangan berbasis web menggunakan metode pengujian black box, dimana pengujian black box adalah pengujan yang dilakukan dengan cara menguji aplikasi dengan memasukan data ke dalam form yang telah disediakan. pengujian black box yang berfokus pada persyaratan fungsional perangkat lunak. Pengujian ini memungkinkan perekayasa sistem mendapat serangkaian kondisi masukan yang sepenuhnya semua persyaratan fungsional untuk 
suatu program. Tabel 2 menunjukan hasil dari kegunaan utama aplikasi telah berjalan dengan baik.

Tabel 2. Pengujian menu halaman

\begin{tabular}{|c|c|c|c|}
\hline $\begin{array}{c}\text { Nama } \\
\text { Pengujian }\end{array}$ & $\begin{array}{c}\text { Bentuk } \\
\text { Pengujian }\end{array}$ & $\begin{array}{c}\text { Hasil yang } \\
\text { Diharapkan }\end{array}$ & $\begin{array}{c}\text { Hasil } \\
\text { Pengujiann }\end{array}$ \\
\hline $\begin{array}{l}\text { Pengujian } \\
\text { login }\end{array}$ & $\begin{array}{c}\text { Mengisi } \\
\text { semua } \\
\text { permintaan } \\
\text { kolom login }\end{array}$ & $\begin{array}{c}\text { Masuk } \\
\text { kehalaman } \\
\text { dashboard }\end{array}$ & Berhasil \\
\hline $\begin{array}{l}\text { Pengujian } \\
\text { Live Stream }\end{array}$ & $\begin{array}{c}\text { Memutar } \\
\text { video di } \\
\text { dashboard }\end{array}$ & $\begin{array}{l}\text { Video dapat } \\
\text { berputar }\end{array}$ & Berhasil \\
\hline $\begin{array}{l}\text { Pengujian } \\
\text { Lupa } \\
\text { password }\end{array}$ & $\begin{array}{l}\text { Mengirim } \\
\text { Token ke } \\
\text { email dan } \\
\text { mengganti } \\
\text { password }\end{array}$ & $\begin{array}{c}\text { Token berhasil } \\
\text { terkirim dan } \\
\text { masuk ke } \\
\text { menu ganti } \\
\text { password }\end{array}$ & Berhasil \\
\hline $\begin{array}{l}\text { Pengujian } \\
\text { Mengunduh } \\
\text { video }\end{array}$ & $\begin{array}{l}\text { Mengunduh } \\
\text { video }\end{array}$ & $\begin{array}{l}\text { Video dapat } \\
\text { diunduh ke } \\
\text { direktori }\end{array}$ & Berhasil \\
\hline $\begin{array}{l}\text { Pengujian } \\
\text { membuat } \\
\text { akun baru }\end{array}$ & $\begin{array}{l}\text { Membuat } \\
\text { akun } \\
\text { baru }\end{array}$ & $\begin{array}{c}\text { Akun baru } \\
\text { terbuat }\end{array}$ & Berhasil \\
\hline $\begin{array}{l}\text { Pengujian } \\
\text { Privillage }\end{array}$ & $\begin{array}{c}\text { Login sebagai } \\
\text { admin dan } \\
\text { user }\end{array}$ & $\begin{array}{c}\text { Menu yang } \\
\text { ditampilkan } \\
\text { berbeda }\end{array}$ & Berhasil \\
\hline $\begin{array}{c}\text { Menampilkan } \\
\text { diagram }\end{array}$ & $\begin{array}{c}\text { Melihat } \\
\text { diagram pada } \\
\text { menu report }\end{array}$ & $\begin{array}{c}\text { Diagram } \\
\text { tampil dan } \\
\text { data sesuai }\end{array}$ & Berhasil \\
\hline $\begin{array}{c}\text { Pengujian } \\
\text { mobike }\end{array}$ & $\begin{array}{l}\text { Melakukan } \\
\text { semua fungsi } \\
\text { dari mobile } \\
\text { browser }\end{array}$ & $\begin{array}{c}\text { Semua fungsi } \\
\text { pada mobile } \\
\text { browser } \\
\text { berjalan }\end{array}$ & Berhasil \\
\hline $\begin{array}{c}\text { Pengujian } \\
\text { dekstop }\end{array}$ & $\begin{array}{l}\text { Melakukan } \\
\text { semua fungsi } \\
\text { dari dekstop } \\
\text { browser }\end{array}$ & $\begin{array}{l}\text { Semua fungsi } \\
\text { pada dekstop } \\
\text { browser } \\
\text { berjalan }\end{array}$ & Berhasil \\
\hline
\end{tabular}

\section{KESIMPULAN}

Dari hasil pengujian dan analisis pembuatan antarmuka sistem pemantau ruangan berbasis web ini dapat disimpulkan bahwa telah dikembangkannya antarmuka untuk sistem pemantau ruangan berbasis web dengan menggunakan bahasa pemrograman PHP dan MySQL. Dengan adanya antarmuka ini, pengguna dapat dimudahkan untuk melakukan proses pemantauan pada suatu ruangan dan dalam pembuatan antarmuka ini telah diuji dengan menggunakan metode black-box dan menunjukan bahwa fungsi-fungsi yang terdapat pada antarmuka dapat berfungsi dengan baik dan sesuai dengan fungsionalitasnya masing-masing serta dapat berjalan dengan baik menggunakan desktop ataupun mobile browser.
Saran yang diberikan dalam upaya pengembangan antarmuka sistem pemantau ruang berbasis web ini ialah antarmuka ini dapat dikembangkan lanjut dengan menambahkan fitur SMS gateway sehingga pengguna dapat menerima pemberitahuan melalui SMS dan dapat pula dikembangkan lanjut dengan menambahkan fitur notifikasi email sehingga pengguna dapat langsung mengetahui terdapat video baru secara langsung dan juga perlu dilakukan penambahan fitur pencarian melalui kalender agar lebih mudah mencari video pada tanggal tertentu.

\section{DAFTAR PUSTAKA}

[1] Arifiyanto, Farid. 2013. Perancangan Prototype web-based online Smart Home Controlled By Smartphone”. TRANSIENT, Vol 2, No.4, http://ejournals1.undip.ac.id/index.php/transient/article/vie w/4307. 13 juli 2016.

[2] Pramu Shinta, Ervika, 2011, “Aplikasi Webcam Untuk Mendeteksi Gerakan Suatu Objek”. http://eprints.undip.ac.id/25283/. 13 juli 2016

[3] Muhammad Shadiq, Hemli.2014.Perancangan kamera Pemantau Nirkabel menggunakan Raspberry pi model B.TRANSIENT, Vol.3, NO.4. http://ejournal-

s1.undip.ac.id/index.php/transient/article/vie w/8124. 13 juli 2016

[4] Panjaitan, Hardi. Perancangan Sistem Informasi Poliklinik USU Berbasis Web menggunakan PHP dan MySQL. Universitas Sumatera Utara. 2014

[5] Supriyanto, A., Pengantar Teknologi Informasi, Jakarta: Salemba Infotek, 2005.

[6] Bakri, Z., dan Hidayaningsih, P. S., "Internet : Pengiriman file,” vol. VII, p. 24, 1997.

[7] Noviyanto, F., dan Ashari, A., "Penerapan Teknologi Ria untuk MembangunAplikasi Web dengan Pengaksesan Real Time (Studi Kasus: Pemesanan Handphone Online)," vol. V, no. 1, p. 486, 2013.

[8] Noviyanto, F., dan Wahyu, D. D., "Rich Internet Aplication (RIA) untuk Aplikasi Sistem Informasi Klinik Kesehatan,” vol. III, no. 2, pp. 341-349, 2015.

[9] Dharma, F., "Pengaruh Structural Assurance dan Perceived Reputation Terhadap Trust Pengguna Internet di Sistem E-commerce,” p. 6, 2006. 
[10] F, M. M., PHP Tutorial Book for Beginner, Yogyakarta: Notebook, 2014.

[11] Widyantoro, Wahyu.Buku Panduan Bootstrap.Margotekno.11 Juni 2015
[12] Ridha, Hafiz. Implementasi Twitter Bootstrap pada Codeigniter. Ilmukomputer.com. 2013 